\title{
A Shared Dilemma: Locating Race in Canadian and American War Stories
}

\author{
Robert Teigrob, Ryerson University
}

Visitors to the US National World War II Museum in New Orleans bask in a profoundly reverent psalm to the country's contribution to the toppling of fascism. The exhibits are designed, notes the official website, to convey "the epic and global scale of the war that changed the world" (emphasis in original). ${ }^{1}$ Viewers could be forgiven for leaving with the impression that those epic changes were effected primarily by the Americans themselves, who, although they countenanced a handful of foreign allies, seemed to tally all of the key goals unassisted. Beyond All Boundaries, the 4-D movie narrated by Tom Hanks, delivers the war's origins, battles, and outcomes in the conventions and motifs of a Hollywood blockbuster. Patrons, young and old, swoon over the gleaming machines of war in the US Freedom Pavilion sponsored by Boeing, a firm that, despite its standing as the world's second largest weapons manufacturer, did not see fit to recuse itself from such a naked conflict of interest. ${ }^{2}$

The greatest generation aura fades, however, when the exhibits turn to issues of race. More than thirty panels in the permanent collection reference the racism that pervaded every facet of American society, from the segregated military to discrimination in wartime industries, from the internment of racial minorities to the profound chauvinism with which white Americans regarded and treated their darker-skinned foreign foes. Photos of black soldiers returning to facilities with segregated entrances and wartime posters depicting the Japanese as repugnant vermin abound; even the panel describing the 2.5-ton CCKW Hard Top transport truck displayed in the Freedom Pavilion informs visitors that many of the drivers "were African American, reflecting a segregated military in which blacks were often relegated to non-combat but essential roles." In this case, an inanimate tool of war, one that formed the backbone of the supply lines established to sustain the Allied rollback of the Nazi empire, carries the permanent mark of the nation's racism and hypocrisy.

Canada's National War Museum reveals the vast gulf that exists between these neighbouring countries when it comes to discussions of race. Visitors to the Ottawa institution are told that Canadians of all backgrounds clamoured to enlist in the nation's foreign conflicts, that Great War volunteers from First Nations were "accepted because of their warrior reputation," and that many Aboriginals, like decorated Ojibwa soldier Frances Pegahmagabow, excelled in their roles. Discussions of who recruiters turned away focus on restrictions related to age and physical capabilities. One panel imagines the modern visitor to be a potential enlistee, and asks whether their teeth are good enough "to chew the sometimes rock-hard military food?" A single panel alludes to the fact that Japanese Canadians hoping to join the 
battle against fascism faced unspecified "official barriers," while another board mentions the fact that following the Second World War "Aboriginal veterans had difficulty getting some benefits." The museum allows that the internment of "enemy aliens" in the world wars was the product of "deep prejudice," but as rendered here, that prejudice exerted only a trifling influence over the make-up of the Canadian military and its conduct abroad. As a corollary, the bugle call had the power to overwhelm domestic divisions among Canadians of various identities, and the country marched with new-found concord to confront its foe.

What follows are some second thoughts on the comprehensiveness of that portrait, and on the wider tendencies among Canadian war chroniclers to gloss over the contradictions between their stated wartime ideals and the lived experiences of the nation's racialized communities. On this matter, the American record is far more comprehensive and soul-searching, despite the fact that visible minorities on both sides of the international divide faced strikingly analogous de jure and de facto proscriptions, circumstances that the crisis of warfare had a way of bringing into painful outline.

While race may be, as Swedish economist Gunnar Myrdal famously intoned, "an American dilemma," that nation's ongoing and often graphic struggle to realize its egalitarian credo has a habit of obscuring a basic truth: from one angle, Canada has always contained a greater percentage of residents who fell outside the dominant ethno-cultural ideal. ${ }^{3}$ In addition to its comparatively larger percentage of Indigenous peoples, Canada features a Francophone community that, throughout the twentieth century, comprised nearly one-third of the Canadian populace. Canadians frequently referred to the two solitudes as distinct races well into that century, believing English and French to embody profoundly divergent and immutable characteristics. ${ }^{4}$ Moreover, Francophones' Catholicism and anti-imperialism, along with systematic discrimination based on their ethnicity, meant that French Canadians were destined to serve as a persistent source of opposition to fighting for a liberal order that distributed its blessings unevenly. ${ }^{5}$ Unlike many dissenters in the US, however, linguistic differences placed at least some limits on the ability of francophones to influence the cultural atmosphere of English Canada. And while their grievances were well-founded, Francophones were not asked to sacrifice on behalf of a country that denied them the right to vote, restricted their movements, and conducted or condoned systematic physical violence against them. Such circumstances did indeed affect many Canadians and Americans, but these were residents set apart by the particularly obstinate divide of skin colour. Lacking the status of visible minority and the harsher proscriptions that went along with it, the basis of francophones' complaints were likewise less visible to many Anglo Canadian observers, who had the habit of ascribing this lack of military enthusiasm to a mishmash of ignorance, naiveté, parochialism, and anti-modernism. ${ }^{6}$

To the extent that these English writers were able to convince their audience that francophones' antiwar position was founded primarily on irrational and 
adolescent sensibilities, they also helped to preserve the affirming image of a nation that fought as an uncomplicated champion of liberal values - along with the disaffirming and paradoxical image of Quebec as the betrayer of those same values. Donald Creighton's monograph summarizing the first one hundred years of the Canadian experiment made this abundantly clear. "French Canadians," he explained, "were colonials and isolationists who saw no reason why Canada should try to play a major part in world affairs... Their dominating purpose was the defence of their own provincial culture, not the establishment of world peace and security." ${ }^{, 7}$ Such reductionist conclusions about the source and nature of francophone sentiments not only purges English Canadian chauvinism from the historical record; it also fails to account for the fact that, when placed in a larger North American context, French Canadians' disinclination to become embroiled in the vagaries of European power politics was hardly unusual.

If the economic and political marginalization faced by Francophones was often underappreciated by English Canadians, the inability among whites as a whole to detect the more systematic exclusions faced by visible minorities would require considerably more effort. In both Canada and the United States, that effort would entail an ability not to see the "whites only" signs affixed to the doors of businesses until the mid-twentieth century, to not be aware of the neighbourhood covenants that prohibited a range of groups from certain districts of the community on account of their skin colour, to not be alarmed by the presence of people of colour at polling stations before certain points of time (e.g., Native Americans prior to 1924, Asians in both countries before the late 1940s, Canadian First Nations before 1960, blacks in the American South prior to 1965). Given the especially grave contradictions between wars for freedom and their own rank in the social order, it should not come as a surprise that racialized citizens would provide some of the more venomous and irrefutable denunciations of each nation's martial contributions to the salvation of foreign peoples. Here the words of Edward Cooper, editor of the Colored American, come to mind. Upon hearing President William McKinley's call for the "benevolent assimilation" of the Filipinos seized in the War of 1898, Cooper wrote, "our white friends have a habit of expending their sympathy upon the black man who is farthest off."

While people of colour faced similar restrictions in both nations, the disparity in the presence of racial minorities as defined (and delimited) by the colour of their skin is significant. Throughout the twentieth century, blacks made up between ten and twelve per cent of the US population. ${ }^{9}$ In fact, the number of American blacks alone eclipsed the total population of Canada in every twentieth-century census, growing from nearly nine million in 1900 to nearly thirty million in $1990 .^{10}$ By the beginning of the twenty-first century, blacks were surpassed as America's largest minority by Hispanics, a group that had grown rapidly since the Second World War, while the percentage of Americans who did not identify themselves as white rose steadily from just over twelve per cent in 1900 to nearly thirty per cent 
by the end of the century. ${ }^{11}$

Their Canadian counterparts, on the other hand, made up just 3.5 per cent of the population according to the 1901 census, a figure bolstered by the relatively high numbers of Indigenous peoples residing in the recently acquired, and supposedly not yet developed, Canadian north and west. As a result, the percentage of racial minorities reported in 1901 represented the high-water mark of diversity in Canada until the 1971 census, after the liberalized immigration policies of the $1960 \mathrm{~s}$ led to an influx of newcomers from non-traditional sources and an increase in the total percentage of those of non-European origin to 4.4. ${ }^{12}$ By 2001, as a result of the continuation of these trends and a census questionnaire that allowed individuals to cite more than one ethnicity, the proportion of those who declared at least a portion of non-European parentage had risen to roughly seventeen per cent. ${ }^{13}$

While people of colour on both sides of the border faced marginalization that generated adversarial attitudes toward mainstream society, the wide national disparity in overall percentages for much of the twentieth century matters. In the United States, black voters provided a vital pillar of the Democratic Party coalition from the New Deal onward, and the importance of their labour to industry and agriculture could at times shape executive policy to profound degrees. The millions of American blacks, Hispanics, and Asians provided a critical mass that could support a wide variety of newspapers and journals, radio stations, voluntary organizations, political lobbies, advocacy groups, and in the case of blacks, their own colleges and universities. The National Association for the Advancement of Colored People (NAACP) counted 90000 (predominantly black) members and 300 local branches in 1919, a membership figure nearly equivalent to the total number of Canada's Indigenous peoples, that nation's largest ethnic minority group (though a group comprised of a range of disparate cultural and linguistic communities); by the end of the Second World War, the NAACP boasted nearly half a million members. ${ }^{14}$ In the early 1920s, at least one million Americans joined Marcus Garvey's Universal Negro Improvement Association, an organization that, unlike the elite-led NAACP, was a mass-based international movement open only to blacks. ${ }^{15}$ Historian Robin Winks outlined some of the disparities in publishing: in 1915, J.R.B. Whitney of Toronto established the weekly Canadian Observer, hoping to establish it as the official voice of black Canadians. By 1921, the Observer was gone, leaving no serials printed for African Canadians at a time when there were 492 such publications produced by and for African Americans. The ethnic publications that flourished in Canada over the course of the twentieth century tended to be those that served linguistic minorities in their native tongue - rendering their views less accessible to most Canadians of the day, and not incidentally, to future historians conducting their work in English. ${ }^{16}$ Racialized Americans possessed, in other words, a greater capacity to make their voices heard.

But there is more to the relative visibility of aggrieved groups than mere numbers: the conspicuousness of the adversity they face certainly contributes to 
the intensity of their resistance, and it can be argued that one finds more abundant, and prominent, expressions of acute racism in the American narrative than the Canadian. This is partly a function of scale: on the one hand, more frequent encounters with racialized individuals provide more opportunities for expressions of racism; on the other hand, higher percentages of minorities provide a greater level of perceived threat to those that seek to maintain hierarchies that work in their favour. It should not be surprising, then, that some of the more flagrant episodes of racial animus in modern Canadian history were set in British Columbia, with a significant percentage of residents of Asian descent, and in Nova Scotia, home to large numbers of African Canadians (some of whom took to referring to their province as "the Mississippi of the North" as a result). ${ }^{17}$ For the most part, as Winks wrote in an observation that could be applied to Canadian racial minorities as a whole, Canada's black community was not "sufficiently numerous, organized, or politically oriented to make up a voting bloc, gain power, or to attract hatred because of their political potential." 18

Canadian blacks and other minorities certainly attracted hatred, discrimination, and violence, but, as Winks' quote implied, anxieties over their ability to gain influence in the public sphere never approached levels witnessed in the United States. Persistent fears over the potential power of American blacks, in particular, provoked a consistent and fierce backlash. Lynching, an act of white terrorism aimed in large part at policing racial boundaries in the American South, claimed approximately 5,000 (mostly black male) victims in the century following the Civil War, and just one in Canada over that same span. ${ }^{19}$ (The lone Canadian lynching victim, meanwhile, an Aboriginal youth named Louie Sam, was murdered by an American mob that crossed the Washington-British Columbia border to avenge a murder that Sam, as it was later revealed, did not commit. $)^{20}$

Significant episodes of racial violence did erupt in Canadian communities - for instance, in 1784 in Shelbourne and Birchtown, Nova Scotia, over labour competition between blacks and whites; in Vancouver in 1887 and again in 1907 over the rising numbers of Asians; in Depression-era Toronto by nativist groups against Jews; in Halifax in 1919 when returning Canadian troops and local whites destroyed Chinese restaurants, and in that same city in 1991 after several black men were denied access to a nightclub. ${ }^{21}$ The American record of race riots is considerably more extensive; such incidents have been chronicled, by way of comparison, in a twovolume, 930-page, 300-entry Encyclopedia of American Race Riots. ${ }^{22}$ The world wars proved particularly conducive to creating the conditions for racial violence, as millions of blacks relocated to urban centres to work in war industries; others served overseas and returned home expecting compensation for their sacrifice in the form of the same freedoms they had helped deliver to Europeans. Whites wedded to the status quo in the workplace, neighbourhood, and the broader social hierarchy were instrumental in fomenting more than twenty-five riots in the bloody Red Summer of 1919 alone; a similar wave of major racial violence swept the nation in $1943 .{ }^{23}$ 
If numerical strength, subjugation, and resistance exist in a triangular relationship, the greater visibility of activism and militancy among American minorities finds additional explanation in these conditions.

Canada's proximity to, and preoccupation with, the United States has also worked to amplify perceptions of national differences regarding race. The United States, the thinking goes, is the nation confounded by a race problem; an ideology of racelessness thus emerges as one means of establishing Canada's status as unor anti-American. ${ }^{24}$ In the nineteenth century, as the American battle over slavery propelled the nation toward civil war, a powerful myth emerged that the institution had never existed in Canada (approximately 3,000 people of African descent toiled as slaves in what would become Canada before 1834); through much of the twentieth century, historical studies of the African-Canadian experience portrayed Canada as a straightforward haven of refuge offering social and legal equality to blacks fleeing American repression - assumptions that dissolved under the weight of later scholarly analysis, but still retain power in contemporary discourse. Canada's interactions with its First Nations peoples have also been held up as evidence of a more tolerant society - although scholars continue to debate the merits of those claims. Regardless, these dynamics have given struggles over racial matters a lower profile in the recounting of the Canadian story. ${ }^{25}$

The visibility of America's race problem has also been enhanced by the attention paid to all things American by supporters and detractors alike the world over. The international influence of US culture, politics, and finance rendered the American story an international concern, and the ability of American liberalism to remedy racial inequities provided something of a litmus test for US claims of global leadership, particularly among people of colour within and beyond US borders. Accordingly, by the mid-twentieth century, the State Department's file included an international cultural exchange program aimed, in large measure, at reversing negative perceptions of American racial politics among foreign governments and peoples. Racial activists, understanding the power they wielded under such global scrutiny, simply redoubled efforts to publicize their predicament in hopes of compelling concrete measures, rather than mere public-relations campaigns, from Washington. ${ }^{26}$ Prominent black newspapers and journals circulated widely within and beyond the nation's borders, broadcasting the gains and limits of the American freedom struggle to a worldwide audience. ${ }^{27}$

For a host of reasons, African Americans were frequently in the foreground of public discourses of war and peace. As a significant demographic force with a long history of anti-slavery and anti-racist agitation, the community developed strong, interconnected, and highly politicized institutions and organizations. Moreover, as a people that, until the mid-twentieth century, existed in a polity that countenanced voting restrictions, discrimination in housing, and Jim Crow segregation, and that ignored consistent and often coordinated acts of terror against the black community, African Americans could readily sympathize with colonized peo- 
ples beyond their borders who faced similar affronts, some of whom were their ethnic kin. In fact, since the beginning of the twentieth century, African American spokespersons have articulated a vision of their community as a nation-within-anation, an internally-colonized people who linked their experiences with colonized and racialized peoples abroad. ${ }^{28}$ Not coincidentally, American conflicts that bore the appearance of supporting an imperial agenda - on the part of America or its allies - faced sometimes-withering and highly publicized critiques from American blacks. While many African Americans joined the Anti-Imperialist League during the War of 1898, a group of Illinois blacks who wished to make the links between foreign and domestic tyranny considerably more explicit formed the National Negro Anti-Expansion, Anti-Imperialist, Anti-Trust, Anti-Lynching League (or NNAEAIATALL for "short"). ${ }^{29}$ In 1907, leading black intellectual W.E.B. Du Bois, a staunch supporter of the Anti-Imperialist League, wrote to its president Moorfield Storey asking for a copy of a photograph published in one of the organization's pamphlets. Du Bois hoped that the image, "After the Battle of Bud Dajo" - which depicted US marines posing triumphantly over a pile of mangled corpses following the butchery of roughly 1,000 Filipino Muslim men, women, and children - could be enlarged, framed, and distributed throughout the United States in order to impress upon Americans "what wars and especially what Wars of Conquest really mean." 30

During the First World War, US officials fretted continuously about the wartime loyalty of the black community, whose leaders routinely castigated the imperial character of the European regimes and the war itself. ${ }^{31}$ Desperately needing their labour and compliance with the draft, and witnessing rising violence between black and white civilians and soldiers, inveterate racist Woodrow Wilson was moved to appoint conservative black leader Emmett Scott as special assistant to the Secretary of War; Scott's mandate was to win blacks over to the cause. ${ }^{32}$ Working in coordination with the Committee on Public Information, Scott strove to convince African Americans that this was not a white man's war or a battle for empire, but "a war of all the people under the Stars and Stripes for the preservation of human liberty throughout the world." ${ }^{33}$

American officials were mostly underwhelmed by the results. In June 1918, the Wilson administration instructed Scott to moderate a secret and what would prove to be contentious meeting between administration officials and black newspaper editors and leaders, who were urged to tone down their persistent criticisms of the war effort. While many complied, federal agents continued to expend considerable resources monitoring and suppressing outspoken journals like The Crisis, the official organ of the NAACP edited by Du Bois, and The Messenger, a black socialist newspaper edited by A. Philip Randolph and Chandler Owen that called on African Americans to resist the draft. Agents infiltrated meetings of advocacy groups like the NAACP, along with black unions and army units, and jailed black leaders like Randolph and Owen who failed to demonstrate satisfactory support for the conflict. ${ }^{34}$ Reigning in black volatility was proving an onerous task. 
If the First World War was, to many black critics, the predictable upshot of imperial rivalries run amok, the Second World War seemed a prime opportunity to abolish the very institution of colonialism itself. Fascist expansion and pogroms justified by racial supremacy demonstrated the logical and dreadful outcome of race-based theories of rule, and Allied talk of the importance of self-government to international stability and prosperity - ideas fundamental to the Atlantic Charter and FDR's Four Freedoms - inspired enthusiastic endorsements of the war effort in the black press and from a broad range of Americans of colour. NAACP leader Walter White, sensing momentum on the colonial issue and drawing on the growing power of black voters in northern electoral districts, corresponded with Roosevelt frequently and was able to secure meetings with the president on several occasions in order to press the matter. ${ }^{35}$

It soon became clear that the administration did not share the same level of enthusiasm for the dismantling of empires as the NAACP and the black community as a whole; for Roosevelt, the desire to maintain the goodwill of European allies in order to win the war necessarily restrained America's anti-imperial efforts. Voices like White's, however, could not simply be dismissed, and throughout the war, American officials were forced to play the demanding, zero-sum game of appeasing their most important international allies and their racialized constituents over the postwar fate of colonized peoples. ${ }^{36} \mathrm{NAACP}$ officials would later vent that the 1944 Dumbarton Oaks Agreement laying the groundwork for the UN demonstrated a "total lack of consideration" of the colonial question and threatened to withhold support for the proposal as a result. Fearful of repeating Woodrow Wilson's failure to rally a cross-section of Americans behind the idea of international governance, the US Secretary of State invited the NAACP to serve as a consultant to the US delegation at the United Nations Conference on International Organization held in San Francisco in the spring of 1945. ${ }^{37}$

The imperial trappings of US wars were not the only source of African American war resistance. American blacks had long bristled at the irony of being asked to lay down their own lives in order to spread liberty, equality, and democracy - ideals at the heart of every public appeal to arms since independence. The truth all too visible to African Americans was that a nation claiming a divine calling to extend liberal ideals did so with an army that for decades rejected black conscripts. Only when the attrition of the Civil War rendered black recruits indispensable to the Union cause did the army relent, although African Americans served in segregated units with segregated blood supplies, and generally under white commanders, long after Hispanics and Native Americans had been accepted into regular combat units. Blacks were also consigned in disproportionate numbers to non-combat duties, limiting their ability to gain military honours and to thereby confirm their standing as the physical and intellectual equals of whites. ${ }^{38}$ (Du Bois acknowledged the potential for racial advancement inherent to military service even as he denounced it, writing: "How extraordinary and what a tribute to religious hypocrisy, is the fact 
that in the minds of most people, even those of liberals, only murder makes men." $\left.{ }^{39}\right)$ And despite President Truman's 1948 executive order desegregating the military, blacks continued to fight in separate units for the first year of the Korean War, as military officials, backed by southern Democrats who controlled important congressional committees, simply ignored the new law. Outrage over this intransigence from the black press, the NAACP (which sent lawyer Thurgood Marshall to Korea to investigate), and liberal Senators led senior officers to begin integrating units in the summer of 1951, but some all-black regiments were not phased out until late in $1954 .{ }^{40}$

These restrictions were merely the military variation of the denial of basic rights experienced in society at large, yielding a range of responses to war from black leaders: as the above comments by Du Bois indicate, some argued that demonstrations of loyalty and conspicuous contributions to victory would advance the cause of racial equality. In a 1917 editorial in The Crisis, Du Bois urged fellow blacks to "forget our special grievances and close our ranks shoulder to shoulder with our white citizens" during the First World War. ${ }^{41}$ Such a strategy went hand-in-hand with campaigns to give blacks the opportunity to serve in the military on equal terms with whites, and to thereby prove their patriotism, aptitude, and manhood. A desegregated and meritocratic army, so the thinking went, would provide a microcosm for similar transformations in civilian life. While desegregation would have to wait, protests at black colleges and pressure from a range of organizations including the NAACP led the army to allow blacks to serve in combat units and to train as officers. By the time of the armistice, hundreds of blacks had served as officers, while Privates Henry Johnson and Needham Roberts, members of an African American regiment reassigned to the French, became the first Americans to receive France's highest decoration for valour, the Croix de Guerre. ${ }^{42}$ At least within the military, slow progress was being made.

Similar efforts marked American entry into the Second World War. After Congress's declaration of war, the Pittsburgh Courier, the nation's most popular black newspaper with circulation of 350000 (a figure several thousand higher than the Toronto Star, Canada's best-selling newspaper), initiated a nationwide Double-V campaign. The Courier held that black contributions to victory over racist regimes abroad should be used as leverage to achieve victory over racism and segregation at home. In their widespread denunciation of the campaign as untimely and provocative, white newspapers helped to usher Double- $V$ into the wider public consciousness; white citizens need not have expressed sympathy with the campaign to recognize that some Americans found an element of hypocrisy in their nation's war for freedom. ${ }^{43}$ For NAACP leaders, the conflict provided the opportunity "to persuade, embarrass, compel and shame our government and our nation" into concrete action on racial injustice. ${ }^{44}$ Recognizing the need to maintain African American support and subjected to persistent pressure from black leaders, newspapers, and organizations, the Marines and the Coast Guard admitted blacks for the first time, and blacks 
served as tank operators and pilots - also firsts. ${ }^{45}$ The exploits of the so-called Tuskegee Airmen, an all-black fighter squadron trained at the black university in Tuskegee, Alabama, consistently made the front pages of black newspapers and won them grudging support in the mainstream media. ${ }^{46}$

Other prominent black voices counselled the withholding of support for foreign wars until the freedoms fought for abroad were enshrined at home. "Let us have a real democracy for the United States and then we can advise a house cleaning over on the other side of the water," wrote the editors of the Baltimore Afro-American in 1917. ${ }^{47}$ Still other African Americans capitalized on the national emergency instigated by war to demand better treatment as a precondition of support. In 1941, for instance, black union leader A. Philip Randolph threatened to hold a 100000 person march in the nation's capital to protest racial discrimination in government agencies and the defence industries. Alarmed by the prospect of such a public exposé of the hypocrisy of the Four Freedoms in his own nation and unable to placate Randolph with vague promises, FDR issued an executive order that banned discrimination in these sectors and established the Fair Employment Practices Committee to ensure compliance. "For the first time," wrote historian John Jeffries, "FDR had taken major public action on behalf of civil rights; indeed, for the first time since Reconstruction the federal government had created an agency committed to action toward equal rights for African Americans." 48

Victories like this were significant but sporadic. As historian James Westheider observed, despite Du Bois' hope that black contributions to saving democracy in France would help salvage the American variant, racial conditions deteriorated categorically in the immediate aftermath of the First World War. ${ }^{49}$ Two decades later, when blacks returned from a war against fascism to an America unwilling to dismantle segregation, "a certain hope died, a certain respect for white Americans faded," wrote black author James Baldwin. ${ }^{50}$ Their wartime service did, however, politicize many black veterans who believed their sacrifice should count for something. Consequently, black veterans of the Second World War and Korean War formed a core of the burgeoning Civil Rights movement of the 1950s and 1960s. ${ }^{51}$

The black veterans' move from military service to grassroots agitation signalled a wider shift in strategy among black activists. The long-held conviction that service to the nation could be parlayed into the expansion of democratic rights and greater recognition had born little fruit, and talk of utilizing military service as a weapon against racism began to fade. In the midst of an unfolding disaster in Vietnam, and in the context of a draft system that provided exemptions weighted toward privileged Americans, Martin Luther King, Jr. made the continued chasm between US ideals and the lived experience of African Americans explicit. "We were," charged King in a 1967 sermon at Manhattan's Riverside Church, "taking the young black men who had been crippled by our own society and sending them 8,000 miles away to guarantee liberties in Southeast Asia which they had not found in Southwest 
Georgia and East Harlem. So we have been repeatedly faced with the cruel irony of watching Negro and white boys on TV screens as they kill and die together for a nation that has been unable to seat them together in the same schools." ${ }^{52}$ King's speech made headlines; it was, observed historian Joe Allen a "bombshell" that infuriated the Johnson administration and led to venomous denunciations in the mainstream press. The Washington Post proclaimed that King had "diminished his usefulness to his cause, to his country, and to his people." Time has been kinder to the assessment of King's sermon, as it is now regarded, wrote Allen, as "one of the best antiwar speeches in American history." ${ }^{\prime 53}$

Adding to the African American disenchantment with the military was the fact that armed forces integration took place in an era when the United States became increasingly committed to the defence and extension of pro-Western regimes in postcolonial settings. As the percentage of racial minorities in the US armed forces multiplied - through conscription to support wars in Korea and Vietnam, and more generally as a result of woeful employment prospects for minorities in the regular workforce - more and more Americans denied freedom by the United States were required to turn their guns on foreign peoples sharing a similar complexion and predicament. Black writer Clyde Taylor summarized African American thinking on Vietnam: "One attitude ... toward the Vietnamese revolutionaries among resistant Black people is 'No Vietnamese ever called me nigger!' A more radical reaction is 'We are all in the same boat.' The most radical response has been "We are allies." ${ }^{54}$ Black activists also considered the financial costs associated with continual military campaigns particularly unseemly when so many African Americans confronted inadequate housing, education, employment opportunities, and health care. War, in other words, simply intensified black marginality. "By the 1960s," wrote historian Kimberely Phillips, "the idea of combat as a 'right' and a declaration of black citizenship and the military as 'equal opportunity' no longer retained its rhetorical and organizing power for civil rights struggles." ${ }^{\prime 55}$ By decade's end, civil rights organizations had become de facto antiwar organizations, and calls for racial justice were joined by equally strident appeals for peace. ${ }^{56}$ The African American community, always wary about the use of force abroad, had been transformed into a pillar of American war opposition. Enlisted blacks became key figures in an antiwar movement emerging from within the military itself, and like their white counterparts, some African American deserters and draft resisters travelled north to seek refuge in Canada. ${ }^{57}$

Black antiwar exiles were tapping into a long tradition. Since the American Revolution, waves of African Americans quit their country for Canada, and found a land generally free of the more extreme acts of white terrorism that their own nation was unwilling to confront. They did not, however, discover an Eden of racial harmony and equality. Some black Loyalists, anticipating an improved racial climate under the leavening influence of the Crown, found more bigotry in Canada than in the United States, and according to geographer Joseph Mensah, returned to the re- 
public as a result. ${ }^{58}$ Nearly 1,200 gave up on North America altogether, relocating to the British colony of Sierra Leone in 1791. ${ }^{59}$ Upper Canada's Abolition Act of 1793 guaranteed fugitive American slaves freedom and the prohibition of slavery by the British Parliament in 1834 removed whatever fears remained that blacks might be returned to a condition of servitude; still, de jure and de facto discrimination obviated any claims to racelessness that Canadians harboured over the course of the nineteenth and twentieth centuries. A hodgepodge of federal, provincial, and local laws and practices (many adopted directly from the United States) sought to prevent or discourage non-white immigration, citizenship, integration, business and labour competition, and social mobility. In the nineteenth century, Ontario banned African Canadians from running for office or serving on juries, and individual counties prohibited blacks from buying land or obtaining a business license. ${ }^{60}$ Segregation in public transportation, public spaces, and housing was commonplace throughout the country until the mid-twentieth century, and people of colour encountered signs barring them from the entrances to hotels, restaurants, beaches, pools, public parks, and skating rinks. ${ }^{61}$ The city of Edmonton eliminated the need for signage altogether, passing a resolution banning all blacks from the city in $1911 .^{62}$ While blacks had been granted the franchise in 1834, Canadian residents of Chinese and South Asian descent were denied the right to vote until $1947 .{ }^{63}$

Lacking the kind of numbers, resources, and organizational infrastructure enjoyed by their American counterparts, far fewer racialized minorities sought redress through the courts; when they did, the absence of a bill of rights hampered successful legal challenges to race-based statutes and practices. ${ }^{64}$ Indeed, no laws explicitly forbidding discrimination existed in Canada until after the Second World War. While the law did not "impose segregation," observed legal historian James Walker, a series of high court rulings "upheld the right of Canadian individuals, organizations, and institutions to discriminate on the grounds of "race."'65 Thus, some African-Canadian children in Ontario and Nova Scotia continued to attend segregated, and markedly inferior, public schools well into the 1960s. An 1849 Ontario statute authorizing segregation in public education was not overturned until 1964, ten years after the landmark Brown v. Board of Education ruling in the US. ${ }^{66}$ Likewise, some institutions of higher learning and professional training programs clung to a whites-only policy until the $1960 \mathrm{~s}^{67}$ Not surprisingly, this constellation of regulations and practices consigned many of those excluded to the lowest rungs of the economic order.

Through it all, the original inhabitants of the land and the nation's largest ethnic minority remained the poorest Canadians. Canada's Indigenous peoples were, like their American counterparts, internally colonized, forced onto generally unproductive reserve lands and presented with a set of alien political, economic, and legal arrangements by a state whose authority they rejected. In addition to being subjected to many of the day-to-day slights and indignities shared by other non-European peoples residing in Canada, Indigenous groups were forced to hand over their chil- 
dren to a system of residential schooling designed to rid them of their language, religion, and other aspects of the so-called backwardness that rendered them incompatible with the liberal order; exposés of the systematic abuse suffered by children in these settings continue to make headlines. The federal government banned many traditional cultural practices with the same goal of assimilation in mind. Reserve territory guaranteed by treaty was frequently appropriated at a later date, or squatted on or seized by whites. The franchise was not extended to Aboriginals until $1960 .^{68}$

Many of the supposed differences between the experiences of American and Canadian racial minorities were, therefore, simply imagined ${ }^{69}$ Given their standing in the social order, it is to be expected that racialized Canadians exhibited similar reactions to those in the United States when their respective federal governments took their nations into war. Some questioned their obligations to a state and society unwilling to countenance them as equals. Frequently overlooked in the Quebec-v.Rest-of-Canada depictions of the conscription crises, for instance, is the fact that thousands of racialized Canadians organized against the policy in a direct protest against their disenfranchisement. ${ }^{70}$ Concerns over whether racial minorities would serve were one thing; fears that their marginalization might inspire active support for the enemy were quite another. At the beginning of the South African War, rumours circulated that certain Aboriginals, still infuriated over the repression of Indigenous and Métis peoples during the North-West Resistance, wished to travel to South Africa and join the Boers in training their guns on British imperial forces. ${ }^{71}$ In fact, anxieties over arming racial minorities and tutoring them in the art of modern warfare proved a persistent concern among Canadian officials contemplating the makeup of their nation's forces; similar apprehensions led to widespread opposition to black enlistment in the US services prior to the Civil War. ${ }^{72}$

Other Canadians of colour chose to support various wars out of patriotism and the idealistic goals of fighting for democracy and self-determination. Many expressed the conviction that military service would provide indisputable evidence of the qualities racist discourse insisted they lacked - loyalty, competence, and manhood - and trusted that their contribution would spur more favourable treatment for themselves and their kin. Indigenous peoples also believed participation would strengthen their desire for permanent inclusion and autonomy (as opposed to their assimilation) within Canada - sentiments not unlike those expressed by mainstream Canadians who saw participation in the empire's battles as a means of enhancing their nation's sovereignty. ${ }^{73}$ After Laurier dispatched the first contingent of Canadian troops to South Africa in the fall of 1899, for example, a number of First Nations leaders delivered appeals to local Indian agents and federal officials in Ottawa and Britain offering military service. "The Indians of the Saugeen Reserve," noted one letter, "are anxious to go to the Transvaal in case another contingent be sent... They are anxious to show their loyalty." ${ }^{74}$ During the First World War, the Grand Indian Council of Ontario sent a letter to individual tribes that recognized the in- 
congruities of sending their young men to fight for "liberty, freedom and other privileges dear to all nations, for we have none." Yet the council encouraged enlistment and accepted conscription in order to show other Canadians that Indigenous peoples shared "the same instincts" and the "same capabilities." 75 That same conflict inspired a deep desire to serve among some African Canadians, who wished to show their gratitude for the refuge the nation provided "in the dark days of American slavery," as Hamilton journalist George Morton wrote in a letter to minister of militia Sam Hughes. ${ }^{76}$ J.R.B. Whitney, editor of the short-lived black weekly Canadian Observer, saw the conflict as a way to demonstrate to Canadians the fighting prowess already recognized, he maintained, by the enemy. "Germans Dread Colored Soldiers in the Battlefield" read one Canadian Observer headline. ${ }^{77}$ As little had been done to improve racial conditions in Canada between the wars, the nation's entry into the Second World War was accompanied by a similar array of patriotic and practical arguments for full citizen participation. ${ }^{78}$

Like their American counterparts, however, Canadian racial minorities willing to die for their country, liberal ideals, and the advancement of their race were forced to contend with a military establishment largely unmoved by the gesture. Unlike the situation in the US army, however, which established separate, mostly non-combat regiments for black troops, many Canadian racial minorities attempting to volunteer for military service were simply turned away. This was essentially an issue of prejudice meeting scale, as the percentage of racialized Canadians was too low to provide a serious political dilemma for officials over the issue, too low for commanders to risk challenging the chauvinism of their white soldiers for the sake of a handful of potential additions, and too low for the government to assume the considerable cost and effort of creating a segregated army. ${ }^{79}$ Accordingly, colonial secretary Joseph Chamberlain wrote directly to leaders of the Haudenosaunee (Iroquois) Confederacy who had proposed sending troops to South Africa, thanking them for their loyalty and expressing regret at having to decline "their patriotic

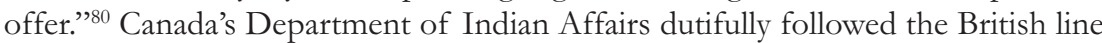
and informed local agents that Indigenous peoples would not be permitted to serve in South Africa. Prospective black and Asian volunteers faced a similar response. ${ }^{81}$

Except for an outright ban on First Nations' enlistment, there was no official policy regarding racial minorities in the early stages of the First World War; the matter was placed in the hands of individual commanders and recruiters, who were generally unified in the practice of accepting only white applicants. ${ }^{82}$ When the oft-repeated assurance (from combatants on both sides) that the war would be "over by Christmas" proved a cruel hoax, Canadian officials prosecuting a total war came to see the illogic of rejecting willing applicants for overseas service. By the end of 1915, army recruiters were ordered to accept all able-bodied men. A handful of blacks, Asians, and First Nations peoples made their way into regular units, but most applicants continued to face rejection from military officials who simply ignored the directive from Ottawa. In a survey by Military Council of unit command- 
ers, one officer explained that he refused black volunteers because it would be unfair to expect his "fine class of recruits" to be forced "to mingle with negroes." 83 Another stated that neither he nor his men "would care to sleep alongside them, or to eat with them, especially in warm weather." ${ }^{\prime 4}$ The allegedly pervasive fears of mingling could be mitigated, reasoned Canadian Observer editor Whitney, by organizing an all-black platoon. When Acting Minister of Militia and Defence A. Edward Kemp informed parliament that no efforts were underway to organize such a unit, Whitney, who had been advertising for recruits in his newspaper, wrote to the minister to inform him that he had one ready to go. ${ }^{85} \mathrm{He}$ need not have bothered: a subsequent survey of Toronto-area commanding officers found none willing to accept the group. "At a time when Prime Minister Borden had committed Canada to the daunting task of keeping 500,000 men in the battlefields," wrote James Walker, "not a single battalion would take a Black platoon." ${ }^{\text {"86 }}$ Vancouver-area Japanese Canadians who also raised their own unit were met with the same response. ${ }^{87}$

At the end of April, 1916, facing critical manpower shortages and on the recommendation of an internal report which reiterated some of the more demeaning stereotypes regarding black capacity, Canada's military council authorized the creation of a single black construction battalion. A year later the black soldiers left for Liverpool in their own troop ship to avoid "offending the sensibilities of other troops" also making the crossing; military officials discussed, and eventually rejected, sending the segregated vessel across the Atlantic alone and unprotected rather than in a regular convoy during what was described as "one of the worst weeks of unrestricted submarine warfare." 88

In their attempts to maintain and police imprecise and mutable notions of racial hierarchy and classifications of citizenship, Canada's military policies regarding ethno-cultural groups blended equal parts tragedy and farce. Some of the members of the all-black construction battalion had been pressed into service through conscription, a law considered applicable to all British subjects. ${ }^{89}$ In other words, Canadian minorities who were initially informed they were unwanted in the forces were now told they must serve. By January 1918, Borden's government revised the Military Service Act to exempt First Nations and Japanese on the grounds that they did not possess full citizenship rights (and that the government had no interest in extending them). Three months later, another order exempted all British subjects prohibited from voting at the federal level from military service; three months after that, East Indians were granted an exemption even though, deprived of the franchise, they had been covered by the previous order. ${ }^{90}$ Having long possessed the right to vote, African Canadians were given no such latitude despite their undeniable status as second-class citizens. Unsurprisingly, several years of humiliating rejection, increasing awareness of the horrors of trench warfare, and reports from the handful of visible minorities in the Canadian Expeditionary Force (CEF) about the bitter racism they encountered from fellow soldiers, dissipated much of the earlier enthusiasm for enlistment. ${ }^{91}$ Officers hitherto panicked by the prospect of including 
African Canadians in their units now complained to military headquarters that a number of blacks had slipped across the border to avoid performing their solemn duty. One Ontario commanding officer wrote to another, recommending that "to obtain these men that rightfully belong to us," the military would need to actively hunt down uncooperative blacks. It is unlikely that the reason for black draft resistance advanced in that letter - that "the average negro is rather 'afraid of the Army" - would be moderated by this proposed military roundup of black civilians. ${ }^{92}$

Perhaps most incongruously, little moral or administrative enlightenment was gleaned from the Great War experience of rejecting certain classifications of willing applicants in times of personnel shortages; when Canada joined the Second World War, many volunteers again found that the pigmentation of their skin rendered them unwelcome. As with the First World War, Ottawa left the matter of recruitment up to the discretion of individual commanders, who once again responded to a survey on the enlistment of African Canadians with claims that white troops would refuse to fight in, or even sign up for, an army that welcomed blacks. ${ }^{93}$ The jarring dissonance between these sentiments and the rationale for a war against fascism did not appear to strike those queried. Moreover, while official recruiting policy stated that the army welcomed anyone demonstrating suitable levels of fitness and education, these variables could serve as stand-ins for race when commanders wished to discourage undesirable recruits (in addition to the fact that poverty and segregation correlate strongly with poorer health and lower levels of education). ${ }^{94}$ Still, the army constituted the branch most welcoming to Canadians of colour. Until 1943, the Royal Canadian Air Force simply prohibited the enlistment of men who were "not both of pure European descent and the sons of natural born or naturalized subjects"; the navy's proscription against enlistees not "of the white race" remained until after the D-Day invasion of June 1944. ${ }^{95}$ And once again, groups willing to enlist in the army but discouraged or banned on the basis of skin colour would be ordered to do so when conscription was reintroduced in 1944.

The confusion, inconsistency, frequent revision, and most of all, hypocrisy of the Canadian military's racial policies inspired abundant, vigorous, and compelling counter-arguments from those most affected. During the First World War, letters from prominent African Canadians objecting to the near-universal rejection of black volunteers at a time of scarce recruits reached Prime Minister Borden and Minister of Militia Sam Hughes. When Borden's government introduced conscription, First Nations peoples and Japanese Canadians delivered a wave of petitions to Ottawa and London protesting the imposition of citizenship duties on those who did not possess citizenship rights. ${ }^{96}$ Indigenous anti-recruiters hounded official recruiters sent to reserves, "reminding Indians of their grievances and the many government promises made to them which had been broken throughout history." 97

The reprisal of prejudicial recruiting in the Second World War incensed a group of black Halifax veterans, who were left to conclude that their Great War sacrifice had gone unrecognized and wrote the Minister of National Defence to 
say as much. ${ }^{98}$ When First Nations were once again conscripted in 1944, a sympathetic Department of Indian Affairs agent from British Columbia explained to his superiors that the low enlistment figures from his region were due to the Navy's blanket rejection of Aboriginal applicants. "It is this discrimination against the B.C. Indian that has made them oppose being called up and put in the army," he wrote. ${ }^{99}$ Other letters, band resolutions, and petitions pointed to First Nations' exclusion from schools, hotels, government jobs, and the legislative process as fundamentally incompatible with their inclusion under the provisions of the Selective Service Act. ${ }^{100}$ The fact that the wars were fought under the banner of bringing liberty to others only deepened the sense of betrayal. Canada's visible minorities, in other words, articulated responses to their nation's wars that were frequently indistinguishable from those voiced by their American counterparts. The similarity of their plight, along with the links between Canadian and American racialized groups forged through transnational alliances - and in Canada, via the popularity of American-based minority newspapers and journals - provoked strikingly similar protestations against government policy and the wars themselves.

Distinct differences existed, however, in the ability of minority groups to make their grievances known to the wider public, and by extension, to find a prominent place in the national memory of the war. As indicated above, in Canada the preponderance of objections to exclusionary and prejudicial policies took place out of public view: in letters and petitions to politicians, Bureau of Indian Affairs agents, and military officers; in correspondence between First Nations bands, and in meetings where military recruiters sparred with draft resisters. Publications by and for racial minority groups were virtually non-existent, however, and most public information on the activities and mood of racialized Canadians in wartime was set down in the mainstream media. Never a mainstay of sensitivity to the particular concerns of non-canonical Canadians, wartime patriotism and censorship intensified media organizations' emphasis on consensus, unity, and state boosterism. Accordingly, stories on the responses of ethnic minorities to war, when they appeared at all, were heavily invested in establishing that Canadians as a whole demonstrated broad support for the war effort. Countless daily papers celebrated First Nations' donations to Victory Bonds, the residential schoolchildren who made clothing to support the war effort, and the women, children, and elders who pulled together to keep their reserves functioning in the absence of enlisted men. ${ }^{101}$

In all, wrote Sheffield, positive Indigenous responses to the war effort were "eagerly reported in the nation's media."102 By contrast, the widespread objections to military service based on the indignities of being refused service, denied access to high school, the workforce, and the voting booth, and treated as children and wards, were generally confined to letters, memoranda, and petitions found in the files of the Department of Indian Affairs and other federal agencies. These were not the types of stories likely to be run by a wartime media committed to inspiring loyalty and unity, and to proclaiming the merits of a crusade for liberty con- 
ducted abroad. This, despite Sheffield's finding that "the marginalized place of Status Indians in the social and legal landscape of Canada," rather than treaty rights, worries over labour shortages on reserves, or any other concerns, served as "the most prevalent issue raised by First Nations opponents of conscription."

Although the obstacles to full inclusion confronting Canadian and American racialized groups bore striking similarities, and wars fought to extend liberal ideals placed domestic racial exclusions under a particularly unflattering glare, the spotlight directed on American action and inaction on these injustices was always brighter. Visibility, however, did not always, or even often, translate into progress concerning the American dilemma. Still, the conspicuous clamour over race in wartime America made the issue an important component of the story of war itself. It is difficult to find a book-length survey of US involvement in the Second World War written since the 1960 s, for instance, that does not include at least some treatment of matters like the proposed march on Washington and the resultant desegregation of war industries, the Double-V campaign, the ironies of fighting Hitler with segregated forces, the barriers overcome by the Tuskegee Airmen, the irreconcilable persistence of Jim Crow in the years following a war against fascism, and the momentum the Four Freedoms provided to modern civil rights activism. ${ }^{104}$ Indeed, in a spate of volumes produced since the 1980s that took aim at more romantic and pious representations of America at war, racial animus in the civilian and military realms was often the story. ${ }^{105}$ Innumerable specialized studies of the wartime experiences of Americans of colour at home and abroad have reinforced the stature of racial conflict in all its guises in the representation of the war. ${ }^{106}$

Even Tom Brokaw's best-selling and hagiographic The Greatest Generation included an entire section, entitled "Shame," comprised of five chapters dedicated to racial minorities' Second World War experience. "Any celebration of America's strengths and qualities during those years of courage and sacrifice," wrote Brokaw in his introduction to the section, “... will be tempered by the stains of racism that were pervasive in practice and in policy. As it was an era of great glory for America and its people, it was also, indisputably, a time of shame." 107 One effect of this type of remembrance, as John Bodnar noted, is that it "resist[s] efforts to sentimentalize completely what had taken place in the early 1940s." 108 An acknowledgement of wartime racial struggles, even when soft-pedalled, moderates the more simplistic and triumphal narratives of a righteous nation summoned to replace a foreign evil with a liberal democratic order it had perfected at home.

That race plays a less prominent role in the recounting of Canada's military history should not come as a surprise. This particular theme has never received the kind of attention directed at America's difficulties over the issue, a consequence of Canada's smaller percentage of visible minorities and its proximity to the more conspicuous, headline-grabbing racial traumas of the United States. In many parts of the country, however, Canada's edition of Jim Crow proved just as comprehensive and long-lasting as its southern progenitor, and the nation's general racial attitudes 
and policies consciously echoed the practices deployed to maintain white dominance in the United States. The impact of racialized thinking was particularly striking in the Canadian military, where opportunities for people of colour tended to lag behind even those of the rigidly-segregated American forces. Rather than being given an opportunity to prove themselves and gain social acceptance in their own, separate units, many Canadians who sought to enlist were simply rebuffed during the South African War and in the first years of both world wars. When the opportunity to serve finally came, either through dogged campaigning for the right or via the coercion of conscription, the work was generally not the type that would win the recognition and gratitude people of colour considered so vital to their broader social advance. At a time when African American squadrons flew over North Africa and Sicily, and blacks serving on US naval vessels battled German and Japanese warships on the high seas, the Canadian branches of these services clung to a strict, whitesonly policy. Discrimination in war-related industries, meanwhile, was not banned until November 1942, more than a year after the practice was outlawed in the United States. ${ }^{109}$

While the fact that fewer numbers of Canadians were affected by racial ordering in civilian and military life helps to explain the lower profile afforded the issue in that country, it is another thing to suggest that such themes are unimportant to the larger story of war. For nations fighting under the banners of freedom, democracy, justice, and equality, the systematic denial of these principles and ideals at home has a place in the record, regardless of the numbers involved. As in the American context, mindfulness of the bitter racial animus faced by racialized Canadians can moderate some of the self-congratulation surrounding the deliverance of national virtues to a needy world, serving as an indication that a full remembrance of war includes an acknowledgment of societal failings and the pain they brought to some citizens. At the same time that they were subjected to a wartime deluge of radiant proclamations about the virtues of their liberal democracies, visible minorities seeking to contribute to this great cause found that its promises were contingent on skin colour. Remembering in this way, then, affirms that while Canada may have important lessons to share with the world, there is also room for humility about the nation's own efforts to realize the ideals it claims.

Greater attention to the matter of race also serves as a reminder that while Canada fought wars, as Creighton wrote, to establish "world peace and security," 110 some of those conflicts also sought to sustain, rather than dismantle, a racially-ordered world system - "a world-girdling British imperial federation controlled by His Majesty's white subjects," in Desmond Morton's apt phrase. ${ }^{111}$ It was a theme that Americans of colour injected into their national conversation early and often, but one with a far lower profile in the Canadian record. When one learns, moreover, that white Canadians preparing to take on fascism expressed repugnance at the thought of conducting this task alongside blacks, and that many sent to Korea broadcasted in word and deed their deep contempt for Asians, we need to look to 
motivations for Canadian intervention that go beyond facile affirmations of the desire to rid the world of malevolent theories and regimes - to simply, as one volume on Canada's Second World War effort concluded, "preserve the basic human right to be free."112 That was certainly part of the story, though not the whole story, and for some civilians and soldiers alike, not the story at all.

It has taken some time for a discussion of the racial animosity in Canada's military and wider culture to find its way into the record of war. Japanese internment gained greater notice beginning in the mid-1970s, providing a challenge to notions of national innocence and righteousness, and studies of the episode began to raise the complicated story of Asian Canadians' attempts to contribute to the world wars. ${ }^{113}$ Around the same time, First Nations and Métis groups grew increasingly vocal about their omission from the national story of war and their difficulty in accessing veterans' benefits; as a result, historians were alerted to the experience of Canada's "forgotten soldiers," as historian Fred Gaffen called them in the title of his seminal work on the subject from $1985 .{ }^{114}$ Little was said of the role and plight of black soldiers in the world wars until American historian Robin Winks gave the subject some attention in his 1971 monograph on African-Canadian history. Little more was added until Calvin Ruck's 1987 study, aptly titled The Black Battalion, 19161920: Canada's Best Kept Military Secret. ${ }^{115}$

Still, if the paradox embedded in America's racial dilemma and its stated wartime goals provides a consistent leitmotif for US analysts, similar analysis is mostly consigned to specialized studies in Canada, and is absent or lightly handled in many general Canadian war accounts. A recent and encyclopedic study of the three-hundred year history of Canada's army, for example, mentioned the predicament of black soldiers once, admitting that while they initially experienced difficulties enlisting in the First World War on account of prejudice, "pressures for men destroyed most such barriers." 116 With no subsequent discussion of matters like segregated units or the rejection of black, Asian, and Indigenous volunteers in later wars, the reader is left to believe that any racial discrimination in the Canadian army had been overcome, in that war and for all time. As noted in the discussion of the Canadian War Museum that began this paper, the short shrift given to the extensive and often bitter chronicle of racial minorities' struggle for respect and equal opportunity in the Canadian military is not atypical. While such an approach does little to illuminate an unflattering and often overlooked corner of the nation's past, it undoubtedly heartens those who view Canada and its armed forces as straightforward agents of freedom, as well as those who consider race a uniquely American dilemma. 


\section{NO'TES}

${ }^{1}$ National WWII Museum website, http://www.nationalww2museum.org/visit/exhibits/.

2 “Defense News Top 100 for 2012," Defense News, http://special.defensenews.com/top-100/charts/rank_2011.php.

3 The term gained prominence after the publication of Gunnar Myrdal, An American Dilemma: The Negro Problem and Modern Democracy (New York: Harper, 1944).

${ }^{4}$ The oft-used term comes from Hugh MacLennan's novel Two Solitudes (Macmillan of Canada, 1945).

${ }^{5}$ Discrimination in hiring, along with the fact that much of the province's business was conducted in English, helped to consign francophones to the leastskilled sectors of the labour market; the resulting economic equality along linguistic lines persisted into the 1980s. See Cory Blad, Neoliberalism and National Culture: State-Building and Legitimacy in Canada and Quebec (Lieden, Netherlands: Brill, 2011), 95.

${ }^{6}$ For a survey of this body of literature, see Robert Teigrob, "Glad Adventures, Tragedies, Silences: Remembering and Forgetting Wars for Empire in Canada and the United States," International Journal of Canadian Studies / Revue internationale d'études canadiennes, 45-46 (2012): 441-465.

${ }^{7}$ Donald Creighton, Canada's First Century (Toronto: Macmillan, 1970), 142.

${ }^{8}$ Cited in David Mayers, Dissenting Voices in America's Rise to Power (Cambridge: Cambridge UP, 2007), 196.

${ }^{9}$ Adalberto Aguirre, Racial and Ethnic Diversity in America: A Reference Handbook (Santa Barbara, California: ABC-CLIO, 2003), 26.

${ }^{10}$ Frank Hobbs and Nicole Stoops, "Demographic Trends in the 20th Century," US Census Bureau, Census 2000 Special Reports, Series CENSR-4 (Washington, D.C.: US Government Printing Office, 2002), A-21, A25, http://www.census.gov/prod/2002pubs/censr-4.pdf.

11 Aguirre, Racial and Ethnic Diversity, 26. As with any such divisions by race and ethnicity, these numbers do not reflect the reality of mixed ethno-cultural backgrounds, but rather the self-reported primary identity requested by pollsters.

${ }^{12}$ Edward N Herberg, Ethnic Groups in Canada: Adaptations and Transitions (Scarborough: Nelson Canada, 1989), 40-42.

13 Canadian Census, 2001.

14 "NAACP: 100 Years of History," NAACP website, http://www.naacp.org/pages/naacp-history; Timothy C. Winegard, Indigenous 
Peoples of the British Dominions and the First World War (Cambridge University Press, 2011), 71; John W. Jeffries, Wartime America: The World War II Home Front (Chicago: Ivan R Dee, 1996), 115; Mark Ledwidge Race and US Foreign Policy: The AfricanAmerican Foreign Affairs Network (New York: Routledge, 2012), 34.

${ }^{15}$ Mark Ledwidge Race and US Foreign Policy: The African-American Foreign Affairs Network (New York: Routledge, 2012), 34.

${ }^{16}$ Robin Winks, The Blacks in Canada, A History, $2^{\text {nd }}$ ed. (Montreal/Kingston: McGill-Queen's University Press, 1997), 315, 390-2, 402.

${ }^{17}$ On British Columbia, see Peter Ward, White Canada Forever: Popular Attitudes and Public Policy Toward Orientals in British Columbia, $3^{\text {rd }}$ ed. (Montreal: McGill-Queen's University Press, 2002); Nova Scotia's unflattering nickname cited in Oliver Moore, "Burning cross ignites racial tension in Nova Scotia," Globe and Mail, 24 February 2010.

${ }^{18}$ Winks, The Blacks in Canada, 484.

${ }^{19}$ Jacqueline Jones Royster, "Introduction," in Royster, ed., Southern Horrors and Other Writings: The Anti-Lynching Campaign of Ida B. Wells, 1892-1900 (Boston: Bedford Books, 1997), 10.

${ }^{20}$ John Vaillant, "The Lynching of Louie Sam, The Walrus," December 2008. http:/ / walrusmagazine.com/articles/2008.12 — the-lynching-of-louie-sam/

${ }^{21}$ Grace-Edward Galabuzi, Canada's Economic Apartheid: The Social Exclusion of Racialized Groups in the New Century (Toronto: Canadian Scholar's Press, 2006), 79. ${ }^{22}$ Walter Rucker and James Nathaniel Upton, eds., Encyclopedia of American Race Riots (Westport, Connecticut: Greenwood Press, 2006).

23 Ann V. Collins, All Hell Broke Loose: American Race Riots from the Progressive Era to World War II (Santa Barbara, California: ABC-CLIO, 2012), xv-xvi; "Introduction," xiix-I.

24 The phrase comes from Constance Backhouse, Colour-Coded: A Legal History of Racism in Canada, 1900-1950 (Toronto: Osgoode Society for Canadian Legal History/University of Toronto Press, 2001), 14.

25 James W. St.G. Walker, “The Law's Confirmation of Racial Inferiority: Christie v. York," in Barrington Walker, The African Canadian Legal Odyssey, 245; Joseph Mensah, Black Canadians: History, Experiences, Social Conditions (Halifax: Fernwood Publishing, 2002), 43-4; Barrington Walker, "Introduction: From a Property Right to Citizenship Rights - The African Canadian Legal Odyssey," in Walker, ed., The African Canadian Legal Odyssey, 23-4.

${ }^{26}$ For specialized studies of this phenomenon, see Mary Dudziak, Cold War Civil Rights: Race and the Image of American Democracy (Princeton: Princeton University Press, 2000); Brenda Gayle Plummer, Rising Wind: Black. Americans and US Foreign 
Affairs, 1935-1960 (Chapel Hill: University of North Carolina Press, 1996); Penny Von Eschen, Satchmo Blows up the World: Jazz. Ambassadors Play the Cold War (Cambridge, Massachusetts: Harvard University Press, 2006); Penny Von Eschen, Race Against Empire: Black Americans and Anticolonialism, 1937-1957 (Ithaca: Cornell University Press, 1997).

${ }^{27}$ Daniel W. Aldridge, III, “Opportunity Lost: African American Public Intellectuals, the Roosevelt Administration, and the Creation of the UN Trusteeship Council, 1941-1945," Perspectives on International and Multicultural Affairs, 1, 1 (2001), http://www2.davidson.edu/academics/acad_depts/rusk/prima/Vol1Issu e1/opportunity_lost.htm.

${ }^{28}$ See Nikhil Pal Singh, Black is a Country: Race and the Unfinished Struggle for Democracy (Cambridge, Massachusetts: Harvard University Press, 2004).

${ }^{29}$ Stuart Creighton Miller, Benevolent Assimilation: The American Conquest of the Philippines, 1899-1903 (New Haven: Yale University Press, 1983), 127.

${ }^{30}$ W.E.B. Du Bois, The Correspondence of W. E. B. Du Bois: Selections, 1877-1934, Herb Aptheker, ed. (Boston: University of Massachusetts Press, 1973), 136. See also Andrew Bacevich, "What Happened at Bud Dajo," Boston Globe, 12 March, 2006.

${ }^{31}$ Nancy Gentile, The Great War and America: Civil-Military Relations during World War I (Westport, Connecticut: Ford Praeger Security International, 2008), 55.

32 One of the earliest of the now-abundant scholarly studies of Wilson racial attitudes was Henry Blumenthal, "Woodrow Wilson and the Race Question," The Journal of Negro History (1963): 1-10.

${ }^{33}$ Ronald Schaffer, America in the Great War: The Rise of the War Welfare State (New York: Oxford University Press, 1991), 78.

34 Ibid., 79.

${ }^{35}$ Daniel W. Aldridge III, "Black Powerlessness in a Liberal Era: The NAACP, Anti-Colonialism, and the United Nations Organization, 1942-1945," in R. M. Douglas, Michael Dennis Callahan, and Elizabeth Bishop, eds., Imperialism on Trial: International Oversight of Colonial Rule in Historical Perspective (Lanham, Maryland:

Lexington Books, 2006), 89-90.

${ }^{36}$ Cited in Aldridge, "Black Powerlessness," 92.

${ }^{37}$ Ibid., 96.

${ }^{38}$ James E. Westheider, The African American Experience in Vietnam: Brothers in Arms (Lanham, Maryland: Rowan and Littlefield, 2008), 5-8.

${ }^{39}$ Cited in Phillips, War!, 9.

${ }^{40}$ Steven Casey, Selling the Korean War: Propaganda, Politics, and Public Opinion, 1950 - 
1953 (New York: Oxford University Press, 2008), 320-1; Westheider, The African American Experience, 8.

${ }^{41}$ Cited in Schaffer, America in the Great War, 80.

${ }^{42}$ Catherine Reef, $A$ to $Z$ of African Americans in the Military, rev. ed. (New York: Facts on File, 2010), xiii-xiv.

${ }^{43}$ Dan J. Puckett, "Double V Campaign," in Leslie Alexander, ed., Encyclopedia of African American History (Santa Barbara, California: ABC-CLIO, 2010), 745-6; José Eduardo Igartua, The Other Quiet Revolution: National Identities in English Canada, 1945-1971 (Vancouver: University of British Columbia Press, 2006),11.

${ }^{44}$ Cited in Martin Folly, The United States and World War II: The Awakening Giant (Edinburgh: Edinburgh University Press, 2002), 61.

${ }^{45}$ Reef, $A$ to $Z$, xiv.

${ }^{46}$ Steve Estes, I Am a Man!: Race, Manhood, and the Civil Rights Movement (Chapel Hill, North Carolina: University of North Carolina Press, 2006), 31.

${ }^{47}$ Chad Louis Williams, Torchbearers of Democracy: African American Soldiers in the World War I Era (Chapel Hill: University of North Carolina Press, 2010), 24.

${ }^{48}$ John W. Jeffries, Wartime America: The World War II Home Front (Chicago: Ivan R Dee, 1996), 110.

${ }^{49}$ Westheider, The African American Experience, 5.

${ }^{50}$ Cited in Phillips, War! 10.

${ }^{51}$ John Bodnar, "The Good War" in American Memory (Baltimore: Johns Hopkins University Press, 2010), 169-70.

${ }^{52}$ Cited in Marilyn Young, The Vietnam Wars, 1945-1990 (New York: Harper Collins, 1990), 192.

${ }^{53}$ Joe Allen, Vietnam: The (Last) War the US Lost (Chicago: Haymarket Books, 2007), 97; Washington Post cited 99.

${ }^{54}$ Cited in Sylvia Shin Huey Chong, The Oriental Obscene: Violence and Racial Fantasies in the Vietnam Era (Durham, North Carolina: Duke University Press, 2012), 64.

55 Phillips, War! 14.

${ }^{56}$ For an in-depth discussion of these transformations, see Simon Hall, Peace and Freedom: The Civil Rights and Antiwar Movements in the 1960s (Philadelphia: University of Pennsylvania Press, 2005).

${ }^{57}$ Chong, The Oriental Obscene, 67; Frank Kusch, All American Boys: Draft Dodgers in Canada from the Vietnam War (Westport, Connecticut: Greenwood Publishing, 2001), 76. 
${ }^{58}$ Joseph Mensah, Black Canadians: History, Experiences, Social Conditions (Halifax: Fernwood Publishing, 2002), 49-50.

${ }^{59}$ See James W. St. G. Walker, The Black Loyalists: The Search for a Promised Land in Nova Scotia and Sierra Leone, 1783-1870 (Toronto: University of Toronto Press, 1992).

${ }^{60}$ Mensah, Black Canadians, 49-50.

${ }^{61}$ Constance Backhouse, "Bitterly Disappointed" at the Spread of "Colour-Bar Tactics: Viola Desmond's Challenge to Racial Segregation, Nova Scotia, 1946," in Barrington Walker, ed., The African Canadian Legal Odyssey: Historical Essays (Toronto: University of Toronto Press, 2012), 118, 101-166.

${ }^{62}$ Jill Vickers and Annette Isaac, The Politics of Race: Canada, the United States, and Australia, (Toronto: University of Toronto Press, 2012), 82.

${ }^{63}$ John Price, Orienting Canada: Race, Empire, and the Transpacific (Vancouver: University of British Columbia Press, 2011), 145.

${ }^{64}$ Barrington Walker, "Introduction: From a Property Right to Citizenship Rights - The African Canadian Legal Odyssey," in Walker, ed., The African Canadian Legal Odyssey, 32-34.

${ }^{65}$ James W. St.G. Walker, “The Law's Confirmation of Racial Inferiority: Christie v. York," in Barrington Walker, The African Canadian Legal Odyssey, 243.

${ }^{66}$ Backhouse, “'Bitterly Disappointed,” 117-8.

${ }^{67}$ Alvin Finkel, Our Lives: Canada After 1945 (Toronto: James Lorimer \& Company, 1997), 10-12.

${ }^{68}$ David T. McNab, "A Brief History of the Denial of Indigenous Rights in Canada," in Miron, A History of Human Rights in Canada, 99-115.

${ }^{69}$ As Phillip Buckner wrote of the era before official multiculturalism: "In reality - a reality that many Canadians still wish to deny - Canada was not more tolerant of diversity than the United States." (Phillip Buckner, "Nationalism in Canada," in Don Harrison Doyle, Marco Antonio, and Villela Pamplona, eds. Nationalism in the New World [Athens, Georgia: University of Georgia Press, 2006], 114). (99117).

${ }^{70}$ Lisa Rose Mar, Brokering Belonging: Chinese in Canada's Exclusion Era, 1885-1945 (New York: Oxford University Press, 2010), 12.

71 Timothy Charles Winegard, For King and Kanata: Canadian Indians and the First World War (Winnipeg: University of Manitoba Press, 2012), 38.

${ }^{72}$ James W. St.G. Walker, "Race and Recruitment in World War I: Enlistment of Visible Minorities in the Canadian Expedition Force," Canadian Historical Review, LXX, 1 (1989): 1; Bruce A. Glasrud, "Introduction: Black Citizen-Soldiers, 1865- 
1917," in Bruce A. Glasrud, ed., Brothers to the Buffalo Soldiers: Perspectives on the African American Militia and Volunteers (Columbia, Missouri: University of Missouri Press, 2011), 1-2.

${ }^{73}$ Scott Sheffield, “Fighting a White Man's War?: First Nations' Participation in the Canadian War Effort, 1939-1945,' in Geoffrey Hayes,' in Mike Bechtold, and Matt Stymes, eds., Canada and the Second World War: Essays in Honour of Terry Copp (Waterloo, Ontario: Wilfrid Laurier Press, 2012), 69.

${ }^{74}$ Winegard, For King and Kanata, 36-7.

${ }^{75}$ Cited in Peter S. Schmalz, The Ojibwa of Southern Ontario (Toronto: University of Toronto Press, 1991), 230.

${ }^{76}$ Cited in Adam Crerar, "Ontario in the Great War," in David Mackenzie, ed., Canada and the First World War: Essays in Honour of Robert Craig Brown (Toronto:

University of Toronto Press, 2005), 249.

${ }^{77}$ Winks, The Blacks in Canada, 316.

${ }^{78}$ Sheffield, "Fighting a White Man's War?" 73-5.

${ }^{79}$ As Winks wrote of the situation in the First World War, "Hughes's advisors did not favor an all-Negro unit since at least three thousand black volunteers would be needed to keep a regiment in the field for twelve months." At a time when the total African Canadian population stood at roughly 16,000, such a target would have been impossible to reach. (Winks, The Blacks in Canada, 314 [quote] 486).

${ }^{80}$ Cited in Winegard, For King and Kanata, 37.

${ }^{81}$ Winks, The Blacks in Canada, 314.

${ }^{82}$ Walker, "Race and Recruitment," 3-4.

${ }^{83}$ Cited in Winks, The Blacks in Canada, 315.

84 Ibid.

${ }^{85}$ Ibid., 317.

${ }^{86}$ Walker, “The Law's Confirmation,” 254.

${ }^{87}$ Walker, "Race and Recruitment," 7.

${ }^{88}$ Walker, "The Law's Confirmation," 255-6 (first quote); Winks, The Blacks in Canada, 318 (second quote).

${ }^{89}$ Arlene Chan, The Chinese in Toronto from 1878: From Outside to Inside the Circle (Toronto: Dundurn Press, 2011), 66.

${ }^{90}$ Walker, "Race and Recruitment," 19.

91 Ibid., 16-7.

${ }^{92}$ Cited in Sarah-Jane Mathieu, North of the Color Line: Migration and Black Resistance in Canada, 1870-1955 (Chapel Hill: University of North Carolina Press, 2010), 
107.

93 Walker, “The Law's Confirmation,” 291.

94 Ibid.; Sheffield, "Fighting a White Man's War?" 72.

95 Walker, "The Law's Confirmation," 291. See also Allan Douglas English, Cream of the Crop: Canadian Aircrew, 1939-1945 (Montreal/Kingston: McGill-Queen's University Press, 1996), 23-4.

${ }^{96}$ Winegar, Indigenous Peoples of the British Dominions, 152.

${ }^{97}$ Walker, "Race and Recruitment in World War I," 16.

${ }^{98}$ Walker, “The Law's Confirmation,” 291.

${ }^{99}$ Cited in Sheffield, "Fighting a White Man's War?" 73.

100 Ibid., 79-80.

101 Ibid., 69-71, 85 n22.

102 Ibid., 70.

103 Ibid., 79.

${ }^{104}$ John F. Marszalek and Horace D. Nash, "African Americans in the Military of the United States," in Arvarh E. Strickland and Robert E. Weems Jr., eds. The African American Experience: An Historiographical and Bibliographical Guide (Westport, CT: Greenwood Press, 2000), 1.

http:/ / testaae.greenwood.com/doc.aspx?fileID=GR9838\&chapterID=GR98382499\&path=books/greenwood.

${ }^{105}$ For a summary of these works, see David Farber, "War Stories." Reviews in American History 23, 2 (1995): 318.

${ }^{106}$ For an introduction to this vast literature, see Marszalek and Nash, "African Americans in the Military." As these authors wrote, "Blacks in the American Armed Forces, 1776-1983: A Bibliography (1985) by Lenwood G. Davis and George Hall, comps., lists 2,386 books, articles, and dissertations, but this book is already out of date," (Marszalek and Nash, 'African Americans in the Military, 1). 107 Tom Brokaw, The Greatest Generation (New York: Random House, 1998), 183.

108 Bodnar, "The Good War," 175.

109 Walker, "The Law's Confirmation," 290.

${ }^{110}$ Creighton, Canada's First Century, 142.

${ }^{111}$ Creighton, Canada's First Century, 142; Desmond Morton, "Was The Great War Canada's War Of Independence?” Images of a Forgotten War, National Film Board of Canada, http://www3.nfb.ca/ww1/independence.php.

112 David Bercuson, Maple Leaf Against the Axis: Canada's Second World War (Toronto: Stoddart, 1995), 275. 
${ }^{113}$ Ken Adachi, The Enemy that Never Was: A History of the Japanese Canadians (Toronto: McClelland \& Stewart, 1976); Barry Broadfoot, Years of Sorrow, Years of Shame: The Story of the Japanese Canadians in World War II (New York: Doubleday, 1977); Peter W. Ward, White Canada Forever (Montreal/Kingston: McGill-Queens University Press, 1978); Takeo Nakano, Within the Barbed Wire Fence (Toronto: University of Toronto Press, 1980).

${ }^{114}$ Fred Gaffen, Forgotten Soldiers (Penticton, British Columbia: Theytus, 1985). For a summary of subsequent work in this area, see Sheffield, "Fighting a White Man's War?” 67-8.

115 Calvin W. Ruck, The Black Battalion, 1916-1920: Canada's Best Kept Military Secret (Halifax: Nimbus Publishing, 1987).

${ }^{116}$ J. L. Granatstein, Canada's Army: Waging War and Keeping the Peace, $2^{\text {nd }}$ ed. (Toronto: University of Toronto Press, 2011), 72. 